\title{
Effect of reducing medication regimen complexity on glycaemic control in patients with diabetes
}

\author{
TAREK SAMY ABDELAZIZ ${ }^{1}$, KHALED MARZOUK SADEK ${ }^{1}$ \\ ${ }^{1}$ Department of Internal Medicine -Kasr Alainy Hospital- Cairo University Hospitals, Egypt
}

\begin{abstract}
Introduction. Medication Regimen complexity is an important issue of patients care that needs to be addressed. The aim of this study is the safe reduction of regimens complexities. The effect of this intervention on glycemic control was assessed in this study.

Methods. Seventy eight patients were recruited to the study. The entry criteria were non optimal glycemic, non-adherence (as demonstrated by indirect tools), and polypharmacy. The only intervention was the safe reduction of medication regimen complexity. This was done in view of the best practice guidelines; to ensure that all comorbidities are treated with the optimum number of medications for the optimum duration.

There was no change to hypoglycemic regimen. All patients, whose hypoglycemic regimen has changed after the recruitment, were excluded. The primary outcome measure was the change in $\mathrm{HbA}_{1 \mathrm{c}}$ three months after the intervention.

Results. Reducing medications regimen complexities led to a significant improvement of $\mathrm{HbA}_{\mathrm{lc}}$ in the after phase compared to the before phase (mean $\mathrm{HbA}_{\mathrm{lc}}$ in the before phase was $7.7 \pm 0.43 \%$ compared to $6.93 \pm 0.4 \%$ in the after phase. Mean reduction in the $\mathrm{HbAlc}$ was $0.77 \pm 0.23 \%$, p values $<0.001$ ).

Conclusion. Medications regimen complexity constitutes a burden for patients with diabetes. Reducing such regimens might improve glycemic control in those patients. Further studies are needed to confirm this favourable effect on the glycemic control.
\end{abstract}

Keywords: Diabetes Mellitus, Medication Adherence, Glycemic, Glycosylated Hemoglobin A1c, Patient compliance.

\section{INTRODUCTION}

Achieving optimal or near optimal glycaemic control is essential to prevent or delay diabetic micro-vascular complications $[1,2]$.

The prevalence of poor control among patients with diabetes is estimated to be $22-55 \%$ [3]. This was revealed from large scale studies in the United States and Europe [4].

Adherence to medications could be assessed through one or more of the following indicators:

(1) Objective health measures (e.g. $\mathrm{HbA}_{1 \mathrm{c}}$ )

(2) Laboratory indicators (e.g. blood or urinary markers), where a nontoxic marker is added to the medication to enable assaying its level.

(3) Indirect indicators (e.g. pill dispensing and refill records)

(4) Subjective report (e.g. patients' self-reports or others' reports)

(5) Compliance with appointment and use of preventive facilities [5].

Self-reported questionnaires [6] were previously developed and validated as a method of monitoring adherence. The main disadvantage of this method is the overestimation of adherence. Patients do not usually have sharp recollection to provide the correct answers to the questionnaires. Besides, they might not provide honest answers for fear of stigmatisation.

Adherence to diabetic medications varies across different races.

Poly-therapy has been found to decrease adherence in previous reports [7].

Barriers that impede proper glycaemic control have been identified. Low socioeconomic status and lack of psychological support are all important factors.

Overcoming such barriers is essential to achieve better glycaemic control and improve overall outcome.

Increasing patients' awareness, establishing a good physician-patient interaction and minimising prescription complexities, are all important strategies to tackle adherence gaps $[8,9]$.

Poly-pharmacy has multiple definitions in the literature. Some of the definitions are based on numerical values only, while others specify a certain period of medications use [10]. The most widely used definition is the use of five or more medications [11]. Dietary supplementations and over the counter medications are included in the number of medications [12]. 
The Prescription cascade is an important sequelea of poly-pharmacy, where adverse effects of the prescribed medications are misinterpreted as new diseases and consequently new medications are added [13].

Diabetic patients are more prone to polypharmacy than non-diabetics [14].

In a recent meta-analysis, complexity of prescriptions was associated with non-adherence to treatment and increased risk of hospitalization [15].

\section{HYPOTHESIS}

The authors' hypothesis was that medication regimen complexity constitutes both financial and adherence burden to patients. Consequently, elimination of unnecessary medications may result in improved patients' adherence. Improving patients' adherence may lead to the achievement of a better glycemic control. The primary outcome of the study is the change in glycemic control as measured by glycosylated hemoglobin (Hb A1C). All participants' prescription has been thoroughly reviewed in the context of the best practice guidelines.

\section{MATERIAL AND METHODS}

\section{STUDY DESIGN}

This is a prospective cohort study, comparing the difference in the glycemic control as measured by the $\mathrm{HbAlc}$ in the same patient cohort before and after the intervention.

\section{STUDY POPULATION}

A cohort of diabetic patients has been recruited through the outpatient department during their regular visits.

\section{SAMPLE SIZE CALCULATION}

Based on previous estimates of mean and standard deviation from our population, a minimal sample size of 57 was required to detect a mean difference in $\mathrm{HbA}_{1 \mathrm{c}}=0.5$, with $80 \%$ power.

\section{ETHICS STATEMENT}

The study was approved by Kasr Alainy Faculty of Medicine ethical committee. Informed consents were obtained from patients prior to enrolment. Researchers have satisfied themselves that the procedure was fully explained to the participants prior to enrolment. The main intervention being that comprehensive medications review will be carried out. Cessation of the unnecessary medications was done after plotting their indications and duration against the best practice guidelines. The study was conducted in line with the Declaration of Helsinki.

\section{TRIAL REGISTRATION}

The study is registered to clinicaltrials.gov (registration number is NCT03324971).

Patients were recruited from the outpatients department at Cairo University hospitals.

\section{INCLUSION CRITERIA}

All diabetic patients who are eligible by fulfilling all of the following criteria:

1) $\mathrm{HbA}_{1 \mathrm{c}} \geq 7 \%$.

2) Poly-pharmacy: defined as the use of five or more medications.

3) Non-compliance: the patients were surveyed with both direct and indirect methods to identify non-adherence.

\section{SCREENING}

Non-adherence to diabetic medications was suggested by the following indirect methods:

1) Family reports.

2) Self-report adherence scales.

3) Uncontrolled blood sugar readings in spite of the absence of stress factors (infections, surgery). patient.

4) Frequent missed doses admitted by the

5) Unfamiliarly with the diabetic medications and inability to differentiate between diabetic medications and other medications.

6) Any financial burden declared by the patients either directly or indirectly. umbrella.

7) Patients who are not under medical insurance

\section{ASSESSMENT OF NON-ADHERENCE}

We used Morisky Medications Adherence Scale (MMAS-4) to assess non-adherence [16].

The scale is a simple self-reported tool which consists of 4 questions, with dichotomous response (yes or no). A total score of 3-4 indicates low adherence.

The questions were translated into Arabic language. This was the first time the Arabic translated 
version of the questionnaire was used in an Egyptian population. However, this was not the only indicator of non-adherence; other direct and indirect methods were used.

\section{MEASUREMENT OF $\mathrm{HbA}_{1 \mathrm{c}}$}

$\mathrm{HbA}_{1 \mathrm{c}}$ was re-measured 3 months after recruitment into the study.

\section{EXCLUSION AFTER RECRUITMENT}

Any patient, whose diabetic regimens changed after recruitment, due to hospitalisation, illness, stress or patients preference was excluded.

\section{MEDICATION REGIMEN RECONCILIATION}

Eligible patients were recruited to the study. Careful review of the current medications was done. This included meticulous consideration of each medication indication, duration of treatment and benefit/risk of discontinuation. There was strictly no change to the oral hypoglycemic medications or insulin regimens from before to after the intervention. The updated medical guidelines were strictly adhered to, to guarantee that such discontinuation does not affect the appropriate treatment of any of the comorbidities.

\section{STATISTICAL ANALYSIS}

$\mathrm{R}$ software was used to perform statistical analysis [17].

The mean and standard deviations were used to express central tendency and variance. Paired $\mathrm{T}$ test was used to compare the mean $\mathrm{HbAlc}$ from the before to the after phase. Paired T test is the method of choice to compare the means of 2 or more observations within the same group of subjects.

\section{RESULTS}

Figure 1 shows the number of patients who underwent screening, the number of ineligible patients and the number of eligible patients.

Patients' characteristics are shown in Table 1. A total of 78 patients have completed the 3 months study duration. 34 patients were excluded after recruitment due to changes made to their antihyperglycemic medications, provoked by acute illness or hospitalisation. There was a significant reduction of $\mathrm{HbA}_{1 \mathrm{c}}$ in the after phase of the study compared to the before phase Figure 2 (mean $\mathrm{HbA}_{1 \mathrm{c}}$ before the intervention was $7.7 \pm 0.43 \%$ compared to $6.93 \pm 0.4 \%$ after the intervention, mean reduction in $\mathrm{HbA}_{1 \mathrm{c}} 0.77 \pm 0.23 \%$, $\mathrm{p}$ values $<0.001$ ).

The mean number of total medications that were prescribed before entry into the study was $5.18 \pm 0.72$ medication per patient. The correlation coefficient (Kendall tau-b method) between number of medications (other than diabetic medications) and the initial $\mathrm{HbA}_{1 \mathrm{c}}$ was $0.46, \mathrm{p}=0.072$ (moderate correlation).

The mean number of medications after the intervention was $3.86 \pm 0.9$ medication per patient. The mean number of stopped medications was $1.25 \pm$ 0.45 medication per patient. There was a moderate correlation between the number of stopped medications and the change in $\mathrm{HbA}_{1 \mathrm{c}}$ (Kendall tau-b correlation coefficient $=0.52, \mathrm{p}=0.024$ ).

Figure 3 shows total number of omitted medications. The most omitted medications were Gabapentin (18 omissions), Allopurinol (17 omissions) and diuretics (16 omissions).

Table 1

Patients characteristics

\begin{tabular}{|l|c|}
\hline Age & 53.5 years $( \pm 8.9$ years $)$ \\
\hline Sex & $\mathrm{F}(28)-\mathrm{M}(50)$ \\
\hline Duration of diabetes(years) & 8.5 \\
\hline $\begin{array}{l}\text { Diabetic regimen } \\
\text { Insulin }\end{array}$ & 26 \\
Oral hypoglycemic & 35 \\
Insulin + oral hypoglycemic & 17 \\
\hline Total number of medications (before the intervention) & $5.2 \pm 0.8$ \\
\hline Total number of medications per patients (after the intervention) & $3.86 \pm 0.9$ \\
\hline Number of stopped medications & $1.25 \pm 0.45$ \\
\hline $\begin{array}{l}\text { Financial burden } \\
\quad \text { Yes }\end{array}$ & $74 \%(\mathrm{n}=58)$ \\
$\quad$ No & $26 \%(\mathrm{n}=20)$ \\
\hline
\end{tabular}




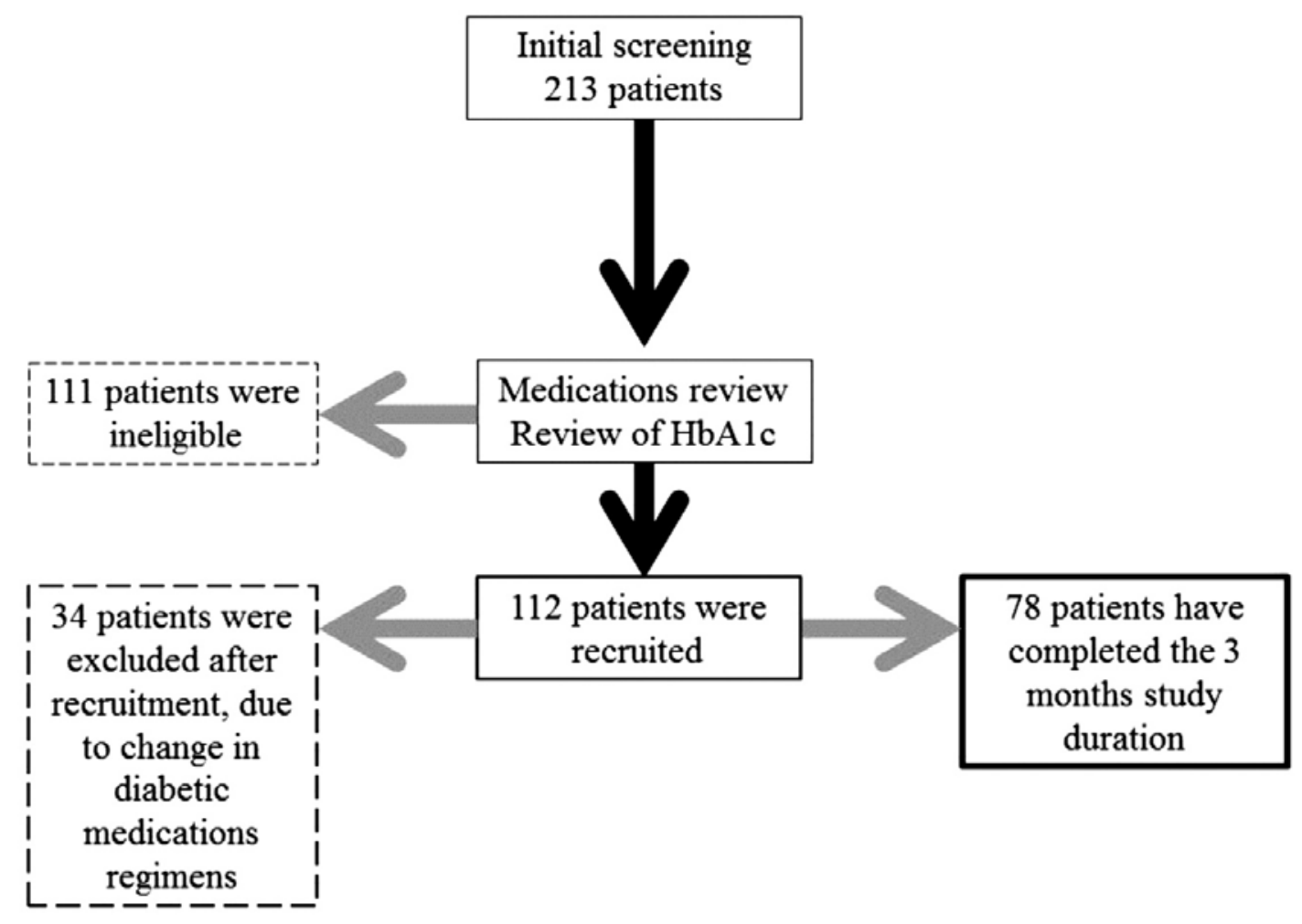

Figure 1. Flowchart of patients screening and recruitment.

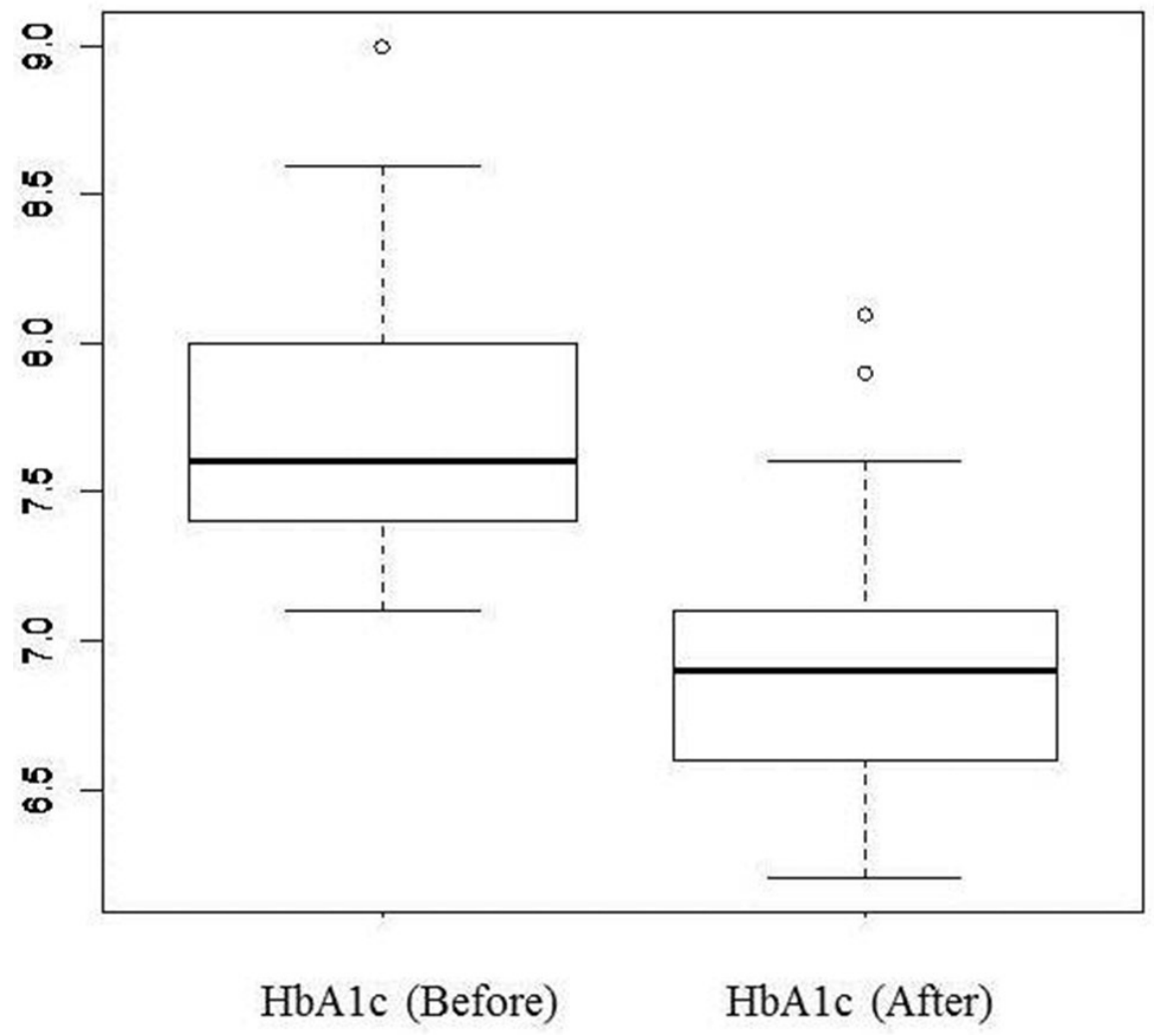

Figure 2. Boxplot showing the difference in HbA1c between the Before and the After phases. 


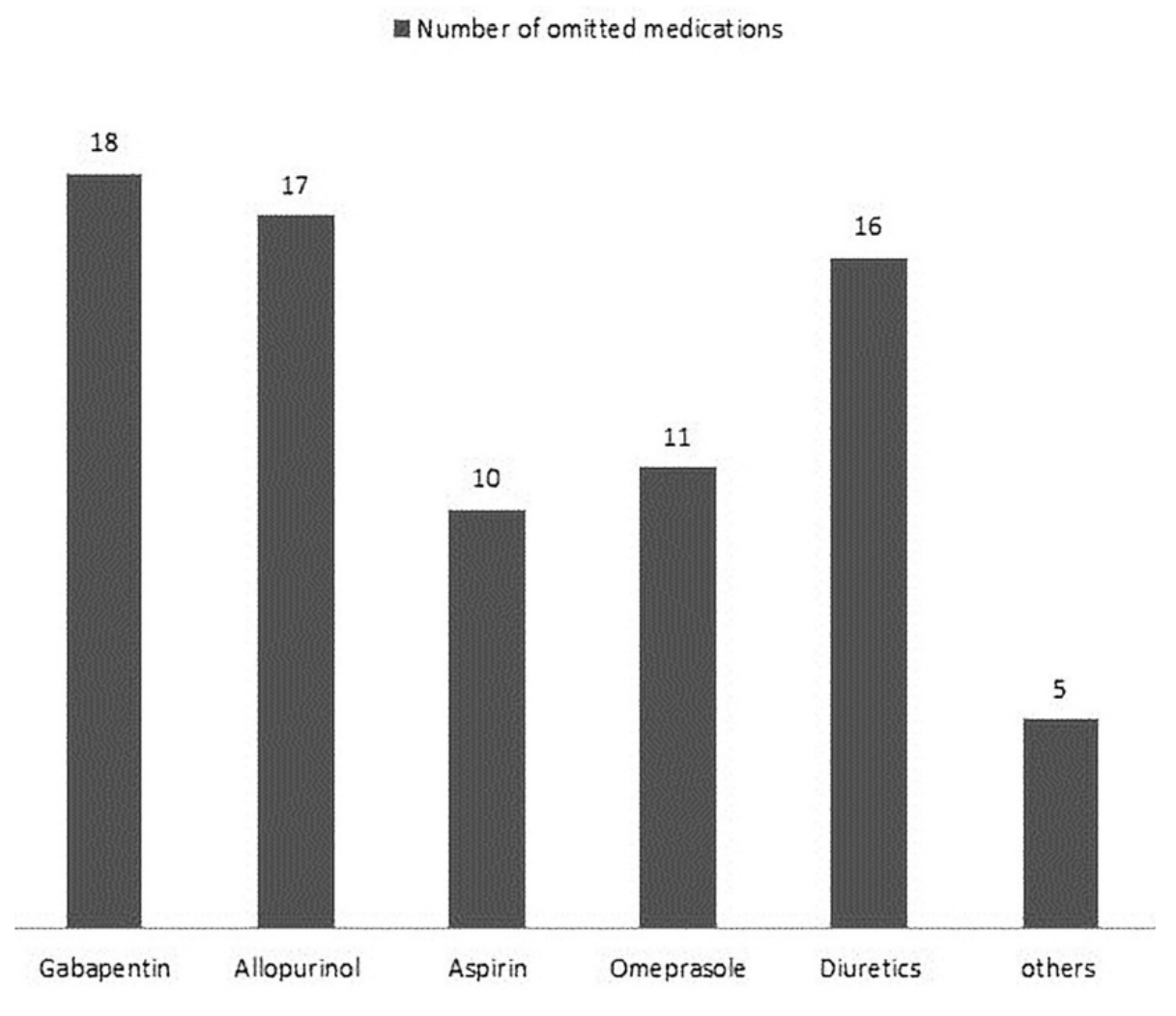

Figure 3. Total number of stopped medications.

\section{DISCUSSION}

Diabetes mellitus is a largely self-monitored disease. There is a broad gap between the treatment recommendations and adherence of patients.

Entry into this study was determined by 2 criteria: poly-pharmacy and non-adherence. The average total number of medications was $(5.2 \pm$ $0.8)$ per patient.

In this study, there was a reduction in $\mathrm{HbA}_{1 \mathrm{c}}$ in the after phase compared to the before phase (mean reduction was $0.77 \mathrm{mg} / \mathrm{dL}$ ). The sole intervention was the elimination of poly-pharmacy. Strictly, no changes were made to the diabetic regimens. Patients whose diabetic regimen changed after the recruitment have been excluded. Large studies have shown that there is poor adherence to anti-diabetic medications in a considerable portion of patients [7]. In a previous systematic review, it was found that adherence to diabetic medications is decreased when more than one diabetic medication is used or more than once daily regimen [18].

In a report by the WHO, the estimated patients' adherence was no more than 50\% [19]. According to this report, improving adherence to diabetes medications, among other chronic medical conditions, leads to a positive impact on the health and expenditure as well [19].

A large French study revealed that good medications adherence was present in no more than $39 \%$ of patients [20]. The important factors associated with the poor adherence to medications were: age $<45$ years, the presence of financial difficulties and $\mathrm{HbA}_{1 \mathrm{c}}>8 \%$.

There was a moderate correlation between the change in $\mathrm{HbA}_{1 \mathrm{c}}$ and the total number of medications. Poly-pharmacy was one of the entry criteria for patients into this study (with a total number of medications per patient $(5.2 \pm 0.8)$. Other studies have revealed similar results in patients with diabetes [12].

In the United States, more than half of the patients report using more than five medications. An average of $20 \%$ of patients use more than 10 medications [21].

The burden of poly-pharmacy is more extensive in the developing countries, where there are no electronic prescribing records. This makes even younger patients prone to poly-pharmacy, due to less restricted accessibility to medications. Polypharmacy can affect adherence in more than one way. Dosing of the important medications could be distracted, leading to improper glycemic control. 
Our study sheds light on the importance of medications reconciliations as an important tool to improve adherence. In a recently published Cochrane systematic review [22], interventions to reconcile polypharmacy decreased inappropriate prescribing. However, this did not translate into meaningful reduction in medications related problems or incidence of hospital admissions. None of the studies included in this systematic review tested $\mathrm{HbA}_{1 \mathrm{c}}$ as a primary outcome. In our study, we only measured $\mathrm{HbA}_{1 \mathrm{c}}$ as a primary outcome but not the mortality or rate of hospitalisation.

Seventy four per cent of the patients included in this study reported having financial burden due to the cost of medications. Complex regimens prescribed by the treating physicians have been identified in some previous studies, as a factor contributing to financial burden and non-adherence.

The study has some limitations. First, a relatively large number was excluded after recruitment due to change in diabetic medication. In an attempt to overcome this, we aimed to recruit a number of subjects exceeding the minimal calculated sample size. We did not see the intention to treat analysis was needed since the total number of patients who completed the 3 months period after the intervention exceeded the estimated sample size.

Secondly, there could be an identified bias resulting from non-pharmacologic improvement of glycemic control of the recruited patients, due to the change in diet or other lifestyle measures. The dietary or lifestyle characteristics of the patients were not monitored. However, there was no specific advice or guidance given to patients regarding the latter aspects.

\section{CONCLUSION}

Medications regimen complexity constitutes a burden for patients with diabetes. Reducing such regimens might improve the glycemic control in those patients. Further studies are needed to confirm this favourable effect on the glycaemic control.

Conflicts of interest: Authors declare that they have no conflict of interest.

Funding: No funds received.

Introducere. Complexitatea regimului medicamentos al diabetului zaharat ridică mari probleme care trebuie studiate. Scopul studiului este de a evalua efectul pe care îl are scăderea regimului medicamentos la persoanele diabetice cu analiza controlului glicemic.

Metode. Au fost recrutați 78 de pacienți. Criteriile de includere au fost un control ineficient al glicemiei, lipsa aderenței terapeutice şi faptul că pacienții erau supuşi unui tratament complex. Intervenția realizată a fost reducerea în condiții de siguranță a complexității regimului medicamentos. Acest aspect a fost realizat in concordanță cu ghidurile actuale. $N u$ s-a schimbat regimul hipoglicemic. Toți pacienții al căror regim hipoglicemic s-a schimbat au fost excluşi. Efectul primar măsurat a fost schimbarea nivelului $H b A_{1 c}$ la trei luni după intervenție.

Rezultate. Scăderea complexității regimului medicamentos a dus la o îmbunătățire semnificativa a $H b A_{l c}(7.7 \pm 0.43 \%$ comparat cu $6.93 \pm 0.4 \%$ după intervenție). Scăderea medie a $H b A_{1 c}$ a fost de $0.77 \pm 0.23 \%, p<0.001$ ).

Concluzii. Complexitatea regimului medicamentos reprezintă un impediment pentru controlul glicemiei la pacienții cu diabet zaharat. Scăderea complexității acestui regim ar putea duce la îmbunătățirea controlului glicemiei. Studii viitoare sunt necesare pentru a confirma acest efect favorabil.

Correspondence to: Dr. Tarek Samy Abdelaziz, M.D, Department of Internal Medicine

Cairo University Hospitals, Cairo, Egypt, Phone: 002/01001572587, Fax: 002025257538

E-mail: taroukah5070@kasralainy.edu.eg

\section{REFERENCES}

1. DIABETES CONTROL AND COMPLICATIONS TRIAL RESEARCH GROUP, NATHAN DM, GENUTH S et al. The effect of intensive treatment of diabetes on the development and progression of long-term complications in insulin-dependent diabetes mellitus. N Engl J Med 1993; 329:977-86. 
2. Intensive blood-glucose control with sulphonylureas or insulin compared with conventional treatment and risk of complications in patients with type 2 diabetes (UKPDS 33). UK Prospective Diabetes Study (UKPDS) Group. Lancet 1998; 352:837-53.

3. ARONSON R, ORZECH N, YE C, BROWN RE, GOLDENBERG R, BROWN V. Specialist-Led Diabetes Registries and Prevalence of Poor Glycemic Control in Type 2 Diabetes: The Diabetes Registry Outcomes Project for AlC Reduction (DROP A1C). Diabetes Care 2016; 39:1711.

4. ALI MK, BULLARD KM, SAADDINE JB, COWIE CC, IMPERATORE G, GREGG EW. Achievement of goals in U.S. diabetes care, 1999-2010. N Engl J Med 2013; 368:1613-24.

5. ROTER DL, HALL JA, MERISCA R, NORDSTROM B, CRETIN D, SVARSTAD B. Effectiveness of interventions to improve patient compliance: a meta-analysis. Med Care 1998; 36:1138-61.

6. SCHECHTER CB, WALKER EA. Improving Adherence to Diabetes Self-Management Recommendations. Diabetes Spectrum 2002; 15:170.

7. CRAMER JA. A Systematic Review of Adherence with Medications for Diabetes. Diabetes Care 2004; 27:1218.

8. ROUMIE CL, ELASY TA, GREEVY R et al. Improving blood pressure control through provider education, provider alerts, and patient education: a cluster randomized trial. Ann Intern Med 2006; 145:165-75.

9. OSTERBERG L, BLASCHKE T. Adherence to Medication. N Engl J Med 2005; 353:487-97.

10. MASNOON N, SHAKIB S, KALISCH-ELLETT L, CAUGHEY GE. What is polypharmacy? A systematic review of definitions. BMC Geriatrics 2017; 17:230.

11. GNJIDIC D, HILMER SN, BLYTH FM et al. Polypharmacy cutoff and outcomes: five or more medicines were used to identify community-dwelling older men at risk of different adverse outcomes. J Clin Epidemiol 2012; 65:989-95.

12. PERON EP, OGBONNA KC, DONOHOE KL. Diabetic Medications and Polypharmacy. Clin Geriatr Med 2015; 31:17-vii.

13. ROCHON PA, GURWITZ JH. Optimising drug treatment for elderly people: the prescribing cascade. British Medical Journal 1997; 315:1096-9.

14. American Diabetes Association. Standards of medical care in diabetes - 2014. Diabetes Care 2014; 37 Suppl 1: S14-80.

15. WIMMER BC, CROSS AJ, JOKANOVIC N et al. Clinical Outcomes Associated with Medication Regimen Complexity in Older People: A Systematic Review. J Am Geriatr Soc 2017; 65:747-53.

16. MORISKY DE, GREEN LW, LEVINE DM. Concurrent and predictive validity of a self-reported measure of medication adherence. Med Care 1986; 24:67-74.

17. R Foundation for Statistical Computing. R: A Language and Environment for Statistical Computing 2017.

18. ODEGARD PS, CAPOCCIA K. Medication taking and diabetes: a systematic review of the literature. Diabetes Educ 2007; 33:1014, 29; discussion 1030-1.

19. BURKHART PV, SABATE E. Adherence to long-term therapies: evidence for action. J Nurs Scholarsh 2003; 35:207.

20. TIV M, VIEL JF, MAUNY F et al. Medication Adherence in Type 2 Diabetes: The ENTRED Study 2007, a French PopulationBased Study. PLoS One 2012; 7:e32412. doi:10.1371/journal.pone.0032412.

21. Slone Epidemiology Center Patterns of medication use in the United States. 2006; 2017.

22. COOPER JA, CADOGAN CA, PATTERSON SM, KERSE N, BRADLEY MC, RYAN C, HUGHES CM. Interventions to improve the appropriate use of polypharmacy in older people: a Cochrane systematic review. BMJ Open 2015; 5:e09235, 2015-009235.

Received July 23, 2018 